\title{
Peter Singer, Jim Mason, Etyka a to, co jemy, przekład Elżbieta De Lazari, pod redakcją językową Doroty Bojarskiej-Lis i Krystyny Podhajskiej, Wydawnictwo Czarna Owca, Warszawa 2012, stron 472
}

Książka jest zapisem rozmów z kolejnego spotkania australijskiego bioetyka, utylitarysty Petera Singera, z pisarzem i prawnikiem angażującym się w walkę o prawa zwierząt - Jimem Masonem. Ich wcześniejsze rozważania na temat chowu przemysłowego zostały poszerzone o zagadnienia dotyczące zdrowej żywności, sprawiedliwego handlu i etycznego konsumeryzmu. $Z$ owych zagadnień powstał przewodnik na temat etycznego podejścia do jedzenia. Jak autorzy sami o sobie piszą, osobliwa $\mathrm{z}$ nich para, która w swojej lekturze używa ciekawej formy gramatycznej „my”, pokazując tym sposobem, że ich opinie na temat etycznego jedzenia, niewiele różnią się pomiędzy sobą. Obaj autorzy podkreślają to z naciskiem: „Osobliwa z nas para - Peter i ja, filozof i chłopiec z farmy - ale i zgrany duet. Uzupełniamy się pod względem tożsamości etnicznej, wykształcenia, historii swoich rodzin, stron świata, z których pochodzimy itd. Dobrze nam się razem pracuje. Domeną Petera jest teoretyczna argumentacja filozoficzna, która poddaje próbie nasze sądy moralne, ja jestem człowiekiem twardo stąpającym po ziemi, wiernym swoim korzeniom. Aby nie komplikować sprawy, w całej książce używamy pierwszej osoby liczby mnogiej, choć nie zawsze razem odwiedzaliśmy farmy i braliśmy udział w wywiadach, zatem forma „my” odnosi się zarówno do nas obu, jak i do każdego z osobna” (s. 12).

Etyka a to, co jemy cieszy się sporą popularnością, ponieważ temat moralnych wyborów konsumenckich związanych z zakupem i komponowaniem posiłków jest często obecny w mediach i z roku na rok przybywa osób dysponujących wiedzą na temat znaczenia takich 
terminów jak fair trade, organic czy GMO (organizmy modyfikowane genetycznie).

Pomimo wieloletniej walki Petera Singera i Jima Masona o prawa zwierząt, omawiana książka nie dyskredytuje osób spożywających mięso i, w dużej części lektury, autorzy dokładają wielu starań, aby zachować obiektywizm i konkretność wywodu. Dopiero w ostatnim rozdziale stawiają nie podlegającą dyskusji tezę, że tak naprawdę właściwa moralnie jest tylko postawa wegańska, z niewielkimi od niej odstępstwami - mam tu na myśli Paris exemption. Oczywiście już od pierwszego rozdziału autorzy starają się odkrywać swe karty, starając się udowodnić, że jedzenie mięsa jest złym wyborem moralnym, jednak zrobią to posługując się rozważnie dobieranymi argumentami, ograniczając subiektywne komentarze, nawet jeśli te same się narzucają podczas niektórych rozmów z hodowcami zwierząt. Nawet osiemnasty rozdział zatytułowany „Co powinniśmy jeść, czyli czego jeść nie powinniśmy”, nie razi fundamentalizmem i czytelnicy nie mogą mieć pretensji do autorów, nawet jeśli czują się przyparci do muru z wielkim symbolicznym graffiti „WEGANIZM ALBO ŚMIERĆ”.

Punktem wyjścia dla całej lektury stały się spotkania $\mathrm{z}$ trzema rodzinami posiadającymi zupełnie różne podejście do kupowania produktów żywieniowych i sporządzania z nich posiłków. Model badawczy zakładał towarzyszenie rodzinom podczas zakupów, analizę poszczególnych produktów i dotarcie do źródła ich pochodzenia. Koleje życia trzech rodzin wyznaczają strukturę książki.

Częścią pierwszą jest spotkanie z Jakiem i Lee - zwolennikami typowej diety amerykańskiej - mięsno-ziemniaczanej, ubogiej w owoce i warzywa, za to bogatej w produkty przetworzone. Jest to sposób odżywiania, który, według całej rodziny, wynika głównie ze względów wygody i redukcji kosztów. Przy okazji lektury pierwszego rozdziału, poznajemy bliżej pierwsze zwierzę hodowlane - ikonę współczesnej amerykańskiej kuchni - kurczaka. Autorzy uprzedzają czytelnika o szokującym opisie, jednak ci, którzy wcześniej przebrnęli przez Wyzwolenie Zwierząt, nie odkryją w nim niczego nowego. Natomiast grupa czytelników, dla której temat hodowli zwierząt będzie czymś 
nowym, po przeczytaniu pierwszych pięćdziesięciu stron, powinni wytrzymać także całą lekturę.

Drugą część stanowią tzw. Moralni wszystkożercy - Jim i Mary Ann, którzy posiadają potrzebę kupowania produktów organicznych a mięso starają się brać tylko z farm, które stosują humanitarną hodowlę zwierząt. Spożywają też więcej warzyw i owoców, redukując tym sposobem mięso w diecie. Autorzy poddają się refleksji, że być może moralna wszystkożerność nie jest najlepszym z możliwych sposobów odżywiania, lecz moralny dystans między tym, co wybierają oni, i tym, na co decyduje się reszta konsumentów, jest ogromny. Dlatego lepiej chwalić ich za to jak daleko w swych wyborach zaszli, niż ganić, że nie posunęli się jeszcze dalej.

Częścią trzecią, najbliższą Singerowi, są weganie - JoAnn i Joe. Rozdział ten jest równocześnie konkluzją rozważań. Od najgorszego modelu, poprzez mniejsze zło, znajdujemy najbardziej etyczne rozwiązanie - dietę wegańską. W książce uzasadnia się taki wybór następująco: „Ponieważ wszyscy jesteśmy często prowokowani do skorzystania z łatwej drogi wyjścia, wyznaczenie wyraźnej zasady (i trzymanie się jej), wykluczającej jedzenie produktów pochodzenia zwierzęcego, może się okazać najlepszym sposobem na to, aby mieć pewność, że nasze konsumenckie wybory są etyczne. Wpływ, jaki możemy mieć na innych, jest jeszcze ważniejszy. Ponieważ hodowla przemysłowa zadaje zwierzętom ogromne, niczym nieuzasadnione cierpienie, przekonywanie innych do jej bojkotu powinno być priorytetowym działaniem dla każdego, komu nieobcy jest los zwierząt." (s. 395) Aby się do takiej diety nie zniechęcić (wiadomo przecież, że produkty wegańskie są mniej rozpowszechnione od tych zawierających produkty odzwierzęce), książka okraszona jest suplementem zawierającym adresy wegańskich restauracji, nazwy wegańskich sklepów, strony i blogi internetowe dotykające kwestii weganizmu, etycznego jedzenia i stosunku do zwierząt, w zależności od tłumaczenia, dla innego kraju.

W książce pojawiła się także kolejna grupa, trochę na zasadzie suplementu - freeganie, czyli anarchiści preferujący antykonsumpcyjny tryb życia, sprzeciwiający się marnowaniu produktów 
żywnościowych, a w praktyce wyszukujący zdatne pożywienie, które trafiło do kontenerów w marketach. Pomimo że słowo freeganizm pochodzi od zbitki wyrazów free - wolny, darmowy i weganizm, z lektury dowiadujemy się, iż wielu zwolenników tego typu podejścia życiowego, stosuje dietę mięsną, tłumacząc, że i tak produkt uległby zmarnowaniu. Temat freeganizmu jest ledwie zarysowany i zdaje się być ciekawostką, z którą zostajemy zastanawiając się, na ile jest to ciekawa alternatywa, a na ile drogowskaz do etycznej konsumpcji. Prosiłoby się o więcej informacji i komentarzy na jego temat.

Czytelnicy zapoznani z lekturą Wyzwolenia Zwierząt Petera Singera, nie oprą się wrażeniu powtarzalności niektórych kwestii. Opisy przetrzymywania zwierząt rzeźnych - ubezwłasnowolnianie cieląt i celowe doprowadzanie do anemii, przetrzymywanie macior w boksach, które nie pozwalają im nawet na zmianę boku, odizolowywanie prosiąt, opisy miniaturowych klatek dla kur niosek, ogromne ilości kurcząt w jednej hali, zbyt mała przestrzeń do stworzenia hierarchii w stadzie; wydaje nam się, że czytamy po raz kolejny to samo. Możemy jednak uznać ten zabieg za celowy - od wielu lat, pomimo prób ulepszenia systemu hodowli zwierząt rzeźnych i wielu ustaw mających na celu dobrostan trzody chlewnej czy drobiu, warunki przemysłowe nie uległy na tyle poprawie, by mówić o etycznej hodowli zwierząt przeznaczonych na mięso, nabiał, jaja i inne.

Książka jest zatem przewidywalna - wiadomym jest, że Singer i Mason posiadają wyraziste przekonania o tym, czego nie powinniśmy jeść. Nie jest to jednak moim zarzutem względem autorów (w szczególności, gdy sama startuję z pozycji weganki i życzyłabym sobie, by ewolucja myśli żywieniowej przebiegała od mięsożerców, po moralnych wszystkożerców aż po wegan). Zresztą autorzy nie namawiają, a pokazują jedynie jak wygląda rzeczywistość, o której wolelibyśmy nie mieć pojęcia. Jedynym zarzutem, który mogłabym wysunąć po lekturze, jest podobieństwo niektórych podrozdziałów do Wyzwolenia zwierząt - mam na myśli opisywanie warunków hodowli zwierząt rzeźnych. O ile, dla nowych w temacie czytelników, przedstawienie tych kwestii jest kluczowe, o tyle, dla zainteresowanych tym wątkiem - zbędne. 
Tłumaczenie książki, którego dokonała Elżbieta de Lazari, jest poprawne. Język, pomimo powagi tematu i odwołań do wielu teorii, praw i autorów, sprawia, że tekst czyta się jak opowiadanie obyczajowe, momentami nawet jak detektywistyczne, a nie jak tekst naukowy. Sam Singer i Mason sprawiają wrażenie sympatycznych i obiektywnych, a takiej konstatacji sprzyja wspomniana przeze mnie wcześniej, forma gramatyczna „my”.

O ponadprzeciętnych walorach omawianej książki stanowią waga i aktualność podjętego tematu, a zwłaszcza kompetencje autorów, odwołujących się tylko do wiarygodnych źródeł informacji. Ponadto książka posiada spójną budowę, która sprzyja sięgnięciu do niej w każdych okolicznościach, również bez większego przygotowania merytorycznego. Uznanie budzi zarówno trafiający do czytelnika podział na części, jak i ciekawa treść przyciągająca uwagę od pierwszego do ostatniego rozdziału, dzięki czemu czytelnik nie nudzi się pomimo niemal pięciuset stron lektury. Książka swoimi treściami wykracza poza kontekst lokalny, dzięki niemu możemy przeanalizować normy przechowywania zwierząt hodowlanych, a także upodobania żywieniowe, w Stanach Zjednoczonych i Europie. Automatycznie pojawi się refleksja: „A jak to jest u nas w Polsce?”.

Z pełnym przekonaniem można zarekomendować tę książkę wszystkim czytelnikom zainteresowanym problematyką etycznego jedzenia, a także tym, którzy bez żadnych refleksji kupują produkty spożywcze, a później komponują jadłospis dla siebie i rodziny. Dlaczego wszystkim? Ponieważ wszyscy, nie licząc bardzo nielicznych wyjątków, (np. odżywiających się Praną), konsumujemy. A skoro jemy, warto poznać dokładną drogę tego, co znajduje się na talerzu. Do takiej refleksji skłania nas zwłaszcza przytoczona przez autorów uwaga: „Kradzież, kłamstwo, wyrządzanie krzywdy innym - owszem, te postępki możemy ocenić jako moralne lub niemoralne. Wielu zaliczyłoby do tej grupy także naszą działalność społeczną, wspaniałomyślność wobec bliźnich w potrzebie, oraz - a może przede wszystkim - życie seksualne. Ale jedzenie - sfera ważniejsza niż seks, która dotyczy nas wszystkich - jest na ogół postrzegana inaczej. Zastanów się, czy kariera polityka mogłaby być przesądzona po 
ujawnieniu tego, co on jada?" (s. 13). Nie usuwajmy zatem refleksji etycznej ze sfery naszej konsumpcji, po to przecież specjalnie powstała prezentowana lektura.

Iga Pastuszek

Uniwersytet Zielonogórski 